\title{
An Enigmatic Protozoan Infection in the Isopod Mesidotea (=Saduria) sibirica from Herschel Island
}

\author{
R.E. KORCZYNSKI ${ }^{1}$
}

\begin{abstract}
The benthic isopod Mesidotea (=Saduria) sibirica from the Herschel Island waters, Yukon Territory, was found to be internally infected with an extracellular protozoan parasite of uncertain identity. The infection is systemic. This is the first reported incidence of an infection in the isopod population in the Herschel Island waters.
\end{abstract}

Key words: isopod, Mesidotea, Saduria, sibirica, protozoan infection, parasite, Herschel Island

RÉSUMÉ: On a trouvé que l'isopode benthique Mesidotea (=Saduria) sibirica, des eaux de l'île Herschel au Yukon, était infecté de façon interne d'un parasite protozoaire extracellulaire à identité incertaine. L'infection est systémique. Voilà la première incidence rapportée d'une infection de la population isopode dans le eaux de l'île Herschel.

Mots clés: isopode, Mesidotea, Saduria, sibirica, infection protozoaire, parasite, île Herschel

Traduit pour le journal par Maurice Guibord.

This is the first observation of a parasitic infection in the isopod Mesidotea sibirica from the Herschel Island waters, Yukon Territory. The finding is important in that the isopod forms an important component of the benthic community, acting as a ravenous scavenger, and serving as food for a variety of fish and marine mammals (Percy and Fife, 1980). With the increased offshore oil explorations in the Beaufort Sea, it is important to differentiate a natural (e.g., parasite) cause of death from an anthropogenic (e.g., oil) cause or those resulting from the synergistic effect of any combination of natural and anthropogenic agents.

Specimens of $M$. sibirica subjected to histopathological analysis were selected at random from baited trap collections. The collections were taken from a deep basin located SE of Herschel Island in July 1975. Mesidotea sibirica inhabits waters between 9 and $40 \mathrm{~m}$ deep in this basin (Percy, 1983). Twenty animals were analyzed: ten sexually mature males and ten females comprising six that were sexually immature, three that were spent, and one that was gravid. The external sexual characters of $M$. sibirica are described in Bray (1962). The isopods were fixed in a $10 \%$ formaldehyde solution buffered with methenamine and then placed in a decalcifying solution of sodium citrate and formic acid. The tissues were dehydrated, embedded, and sectioned by standard histopathological procedures (Korczynski, 1983). Tissue sections were stained with Harris's hematoxylin and eosin.

There is no apparent gross external manifestation of the infection. Internal tissues had no pigmentation or recognizable lesions. The protozoan internally infected $30 \%$ of the animals examined. Infections were categorized as light, medium, or heavy based on the intensity of the protozoan aggregations in the tissues. Three males were heavily infected. One sexually immature female was heavily infected and two spent females had light infections.

The protozoan is extracellular and invades the tissue spaces (Fig. 1) and body cavity (Fig. 2) of the isopod. In heavily parasitized isopods, the infection is systemic. The cellular responses of the isopod toward the invading protozoan include encapsulation and phagocytosis.

The protozoan is present as spores and aggregations. The spore, which had a central dark body surrounded by a membranous envelope, measured $4.03-5.65 \mu \mathrm{m}(\overline{\mathrm{x}}=4.90 \pm$ $0.70 ; n=25)$. Spores were observed less frequently than aggregations. The aggregations consisted of two to hundreds of "cells" that were indistinguishable from spores in appearance and size. The aggregations were irregular in appearance (Fig. 2).

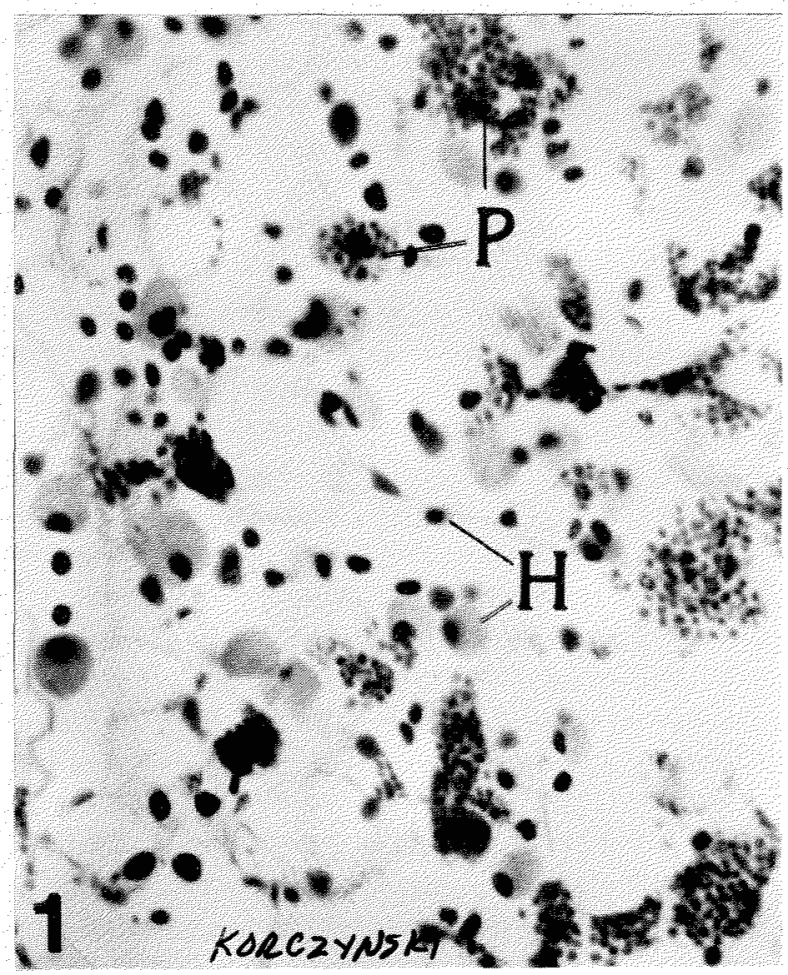

FIG. 1. Invasion of the connective tissue of $M$. sibirica by the protozoan (P) (medium infection). Hemocytes $(\mathrm{H})$ are shown. $\mathrm{x} 250$. 


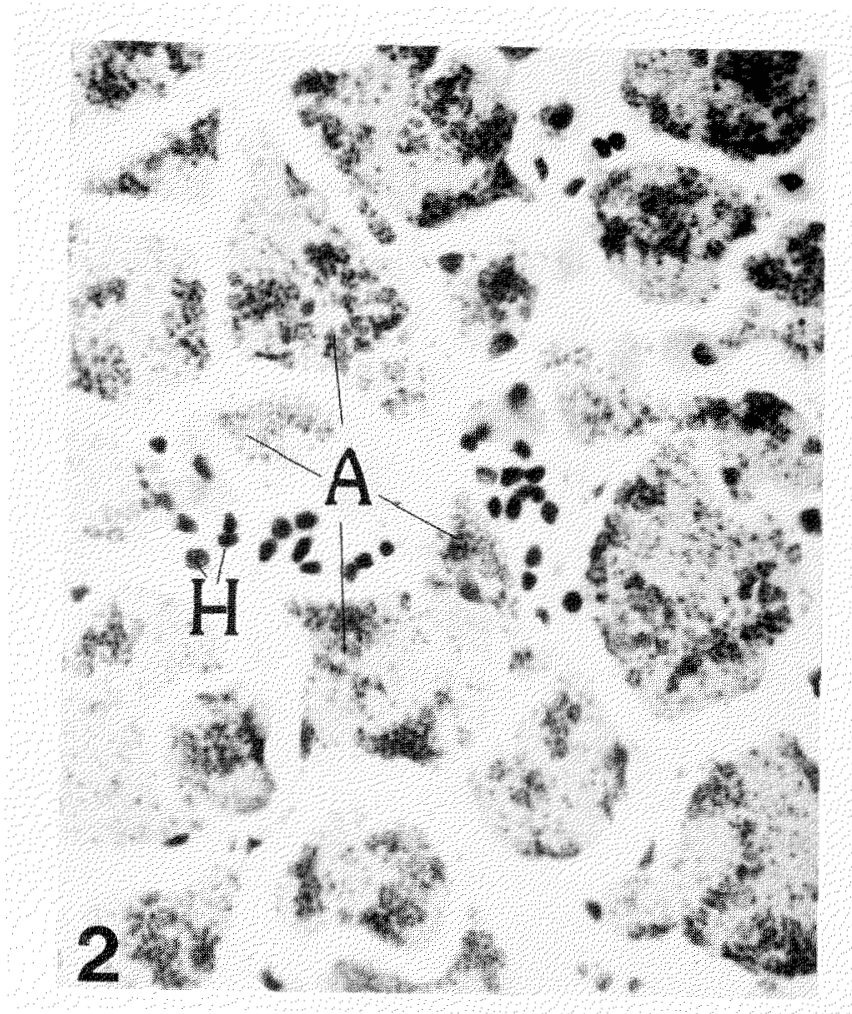

FIG. 2. The body cavity of $M$. sibirica shows dense protozoan aggregations (A) (heavy infection). Hemocytes (H) are shown. x 250.

The protozoan does not resemble a coccidian or gregarine (Levine and Porchet, pers. comm.), nor a microsporidian (Vávra, pers. comm.), as the Microspora are obligatory intracellular parasites that do not form branched plasmodia (Kudo, 1971). Sprague (pers. comm.) did not recognize the parasite as a species of Ascetospora (formerly Haplosporidia). The spore stage of the protozoan suggests it does not belong to the Sarcomastigophora, which typically have no spore formation (Sandon, 1968). It is impossible to identify protozoan parasites from histological sections unless all life history stages are present. Other protozoal stages may be present in other life cycle stages of the isopod (larva and juvenile) and perhaps in animals obtained from other seasons. It may be that an intermediate free-living stage of the protozoan exists or that an alternate host (e.g., fish) is involved to complete the life cycle. The protozoan may be a Myxosporidea, which are primarily parasitic in fishes (Stunkard, 1969). The portal of entry of the protozoan is unknown; however, visible scarring on the exoskeleton and missing pereiopods on the isopods were evident, suggesting that entry may be via a wound.

\section{ACKNOWLEDGEMENTS}

I thank Dr. J. Percy of the Arctic Biological Station, Ste. Anne de Bellevue, Quebec, for access to the isopod collections taken in the southern Beaufort Sea and Arctic Laboratories Limited, c/o Sidney, British Columbia, for use of the histopathology facilities. Thanks also to Drs. N.D. Levine, E. Porchet, J. Vávra, and V. Sprague for viewing and commenting on the protozoan.

\section{REFERENCES}

BRAY; J.R. 1962. Zoogeography and systematics of Isopoda of the Beaufort Sea. M.Sc. thesis, McGill University, Montreal, Quebec, Canada. 138 p.

KORCZYNSKI, R.E. 1983. Comparison of freshwater and saltwater populations of the isopod Mesidotea entomon from Dolomite Lake, Northwest Territories, and Pauline Cove, Yukon Territory. Ph.D. thesis, McGill University, Montreal, Quebec, Canada. 223 p.

KUDO, R.R. 1971. Protozoology. Springfield, Illinois: C.C. Thomas. 1174 p.

PERCY, J.A. 1983. Distribution of arctic marine isopods of the Mesidotea (=Saduria) complex in relation to depth, temperature, and salinity in the southern Beaufort Sea. Arctic 36(4):341-349.

and FIFE, F.J. 1980. Distribution, population structure and reproduction of arctic marine isopods of the Mesidotea complex in the southern Beaufort Sea. Canadian Data Report, Fisheries and Aquatic Sciences $198.91 \mathrm{p}$.

SANDON, H. 1968. Essays on protozoology. London: Hutchinson Educational Limited. $142 \mathrm{p}$.

STUNKARD, H.W. 1969. The sporozoa: with particular reference to infections in fishes. Journal of the Fisheries Research Board of Canada 26:725-739. 